\title{
Deproteinization of Nonammonia and Ammonia Natural Rubber Latices by Ethylenediaminetetraacetic Acid
}

\author{
N. Moonprasith, ${ }^{1}$ A. Poonsrisawat, ${ }^{2}$ V. Champreda, ${ }^{2}$ \\ C. Kongkaew, ${ }^{1}$ S. Loykulnant, ${ }^{1}$ and K. Suchiva ${ }^{1}$ \\ ${ }^{1}$ Natural Rubber Focus Unit, National Metal and Materials Technology Center, 114 Thailand Science Park, Phahonyothin Road, \\ Khlong Nueng, Khlong Luang, Pathum Thani 12120, Thailand \\ ${ }^{2}$ Enzyme Technology Laboratory, National Center for Genetic Engineering and Biotechnology, 113 Thailand Science Park, \\ Phahonyothin Road, Khlong Nueng, Khlong Luang, Pathum Thani 12120, Thailand
}

Correspondence should be addressed to S. Loykulnant; surapicl@mtec.or.th

Received 27 April 2017; Revised 7 July 2017; Accepted 19 September 2017; Published 30 October 2017

Academic Editor: Angela De Bonis

Copyright (C) 2017 N. Moonprasith et al. This is an open access article distributed under the Creative Commons Attribution License, which permits unrestricted use, distribution, and reproduction in any medium, provided the original work is properly cited.

\begin{abstract}
Deproteinized natural rubber (DPNR) was made from sodium hydroxymethylglycinate latex (SH-latex) and ammonia latex $\left(\mathrm{NH}_{3}\right.$ latex) by mixing with different forms of ethylenediaminetetraacetic acid (EDTA) in the presence of sodium dodecyl sulfate (SDS). The mixtures were stirred at room temperature followed by centrifugation to separate the denatured proteins. The optimized reaction contained $0.01 \mathrm{wt} \%$ ethylenediaminetetraacetic acid tetrasodium (EDTA-4Na) with 1\% SDS. The nitrogen contents of the DPNR from SH-latex and $\mathrm{NH}_{3}$-latex were reduced to $0.005 \mathrm{wt} \%$ and $0.008 \mathrm{wt} \%$, respectively, compared to $0.551 \mathrm{wt} \%$ in the starting SH-latex and $0.587 \mathrm{wt} \%$ in the $\mathrm{NH}_{3}$-latex. SDS-PAGE analysis and FT-IR spectroscopy showed decomposition of latex proteins to peptides of smaller molecular weight. Physical properties of the DPNR rubber were studied. The novel EDTA-4Na treatment is considered an effective deproteinization method with potential application on both ammonia and nonammonia preservative systems.
\end{abstract}

\section{Introduction}

Natural rubber (NR) field latex (Hevea brasiliensis) contains $30-40 \%$ rubber by weight dispersed as rubber latex particles in water with some minor nonrubber constituents such as proteins, lipids, carbohydrates, sugars, and metal ions. The rubber particles of fresh rubber latex contain cis-1,4polyisoprene surrounded by proteins and lipids on the outer surface. The protein component of the natural rubber latex particles is believed to be exclusively associated with the particle surface as an adsorbed layer [1]. These proteins present on the surface of NR particles in the latex state may sometimes bring about latex allergy mediated by type I immunoglobulin $\mathrm{E}[2,3]$. The potential protein allergy risk in NR products for sensitized users has resulted in an increasing demand on deproteinized NR latex, particularly for medical devices and hypoallergic products.

Different chemical and enzymatic methods have been reported for deproteinization of NR. NR was effectively deproteinized in the latex stage by enzymatic degradation which removed proteins present on the surface of the rubber particle $[4,5]$. This resulted in marked decrease in the nitrogen content of NR to less than $0.02 \%$, which was approximately $5 \%$ of the starting material [6-8]. However, the enzymatic process requires long incubation time (usually more than $24 \mathrm{~h}$ ) while the remaining proteins, peptides, or amino acids may result in intraoperative anaphylactic reactions of hypersensitive patients of allergy [3,9]. NR treatment with urea and saponification led to reduction in the total nitrogen content to lower than $0.02 \mathrm{wt} \%$ within 1 hour under suitable conditions [6].

The conventional ammonia system for latex preservation using chemicals such as TMTD (Tetra methyl thiuram disulfide) and $\mathrm{ZnO}$ as secondary preservatives that are highly toxic can potentially cause allergy. This leads to an increasing trend on using nonammonia preservatives for fresh latex. Development of an efficient method for deproteinization of NR preserved by nonammonia system is thus of great interest. 
SH preservative has no strong smell, is free of nitrosamine, and is nontoxic to cells. The $\mathrm{pH}$ of SH-latex can be adjustable to $8-11$ which is considered advantageous for subsequent application.

In this present work, the use of ethylenediaminetetraacetic acid tetrasodium (EDTA-4Na) in conjunction with surfactant on deproteinization of nonammonia and ammonia latices was studied. This can potentially cause chelation of the metal ions coordinate with NR proteins, resulting in denaturation and removal of the proteins from NR surface. The deproteinized rubber was characterized for physical properties. This work demonstrates the novel EDTA treatment as an effective alternative for NR deproteinization for preparation of deproteinized latex for allergenic free applications.

\section{Experimental}

2.1. Materials. Fresh natural rubber (FNR) latex was collected by tapping from mature Hevea rubber trees of Thai Rubber Latex Co., Ltd., plantation in Chonburi province, Thailand. Sodium hydroxymethylglycinate $(\mathrm{SH})$ was provided from ISP Chemical (Columbus, Ohio, USA). Ethylenediaminetetraacetic acid, Coomassie Brilliant Blue R-250, sodium dodecyl sulfate, lauric acid, potassium hydroxide, and ammonium hydroxide were analytical grade and supplied by Sigma-Aldrich. Ammonium persulfate, $\mathrm{N}, \mathrm{N}, \mathrm{N}^{\prime}, \mathrm{N}^{\prime}$-tetramethylethylene-diamine (TEMED), and acrylamide were procured from Biorad Laboratories, Inc. (Hercules, CA).

\subsection{Methods}

2.2.1. Preservation of NR Latex. The fresh natural rubber (FNR) latex was divided into two fractions. The first fraction was suddenly preserved by the addition of $0.4 \mathrm{wt} \%$ cosmetic grade preservative, sodium hydroxymethylglycinate $(\mathrm{SH})$ [10], and adjusted the $\mathrm{pH}$ to 10 using potassium hydroxide $(\mathrm{KOH})$ and used as the nonammonia latex sample. The second fraction was added with $0.4 \mathrm{wt} \%$ ammonium hydroxide and used as the ammonia latex sample.

2.2.2. NR Deproteinization. The DPNR latex was prepared by treating FNR latex with ethylenediaminetetraacetic acid sodium (EDTA-Na), ethylenediaminetetraacetic acid disodium (EDTA-2Na), ethylenediaminetetraacetic acid trisodium (EDTA-3Na), and ethylenediaminetetraacetic acid tetrasodium (EDTA-4Na) at various concentrations $(0.05$, $0.10,0.20 \mathrm{wt} \%)$ in the presence of $1 \mathrm{wt} \%$ sodium dodecyl sulfate (SDS) at room temperature for $1 \mathrm{~h}$ with continuous stirring. Then, the treated latex was centrifuged at 10,000 rpm for $50 \mathrm{~min}$. The cream fraction was redispersed in $1 \mathrm{wt} \%$ SDS solution to make $30 \%$ dry rubber content (DRC) latex and washed twice by centrifugation. The obtained cream fraction was redispersed in distilled water to make DPNR of 30\% dry rubber content (DRC) latex. The samples of untreated and deproteinized latices were air-dried. The DPNR latex was coagulated with methanol for characterization of physical properties. The effects of different EDTA salt complexes were studied at $0.10 \mathrm{wt} \%$ of the chelating agent using the

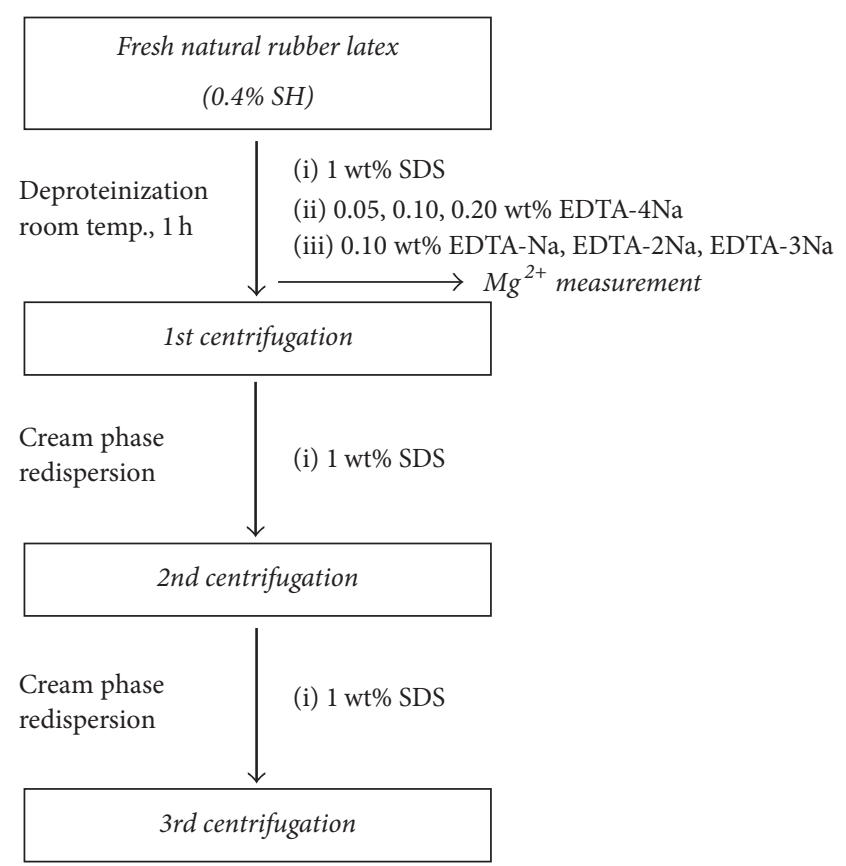

FIGURE 1: Schematic representation of deproteinization procedure.

method described above. The deproteinization procedure is presented in Figure 1.

2.2.3. Analytical Methods. Protein profiles of DPNR were determined by sodium dodecyl sulfate polyacrylamide gel electrophoresis (SDS-PAGE) according to the standard procedure [11] with $4 \%$ stacking gels and $15 \%$ separating gels at a constant current of $15 \mathrm{~mA}$ for $1 \mathrm{~h}$. The molecular weight reference marker was run simultaneously in all experiments. The protein bands were visualized by staining Coomassie Blue R-250.

The total nitrogen content of the NR samples was measured by using the Kjeldahl method according to the Rubber Research Institute of Malaysia (RRIM) test method [12]. Functional groups of NR samples were characterized by Fourier transform infrared (FT-IR) spectroscopy using a Perkin Elmer Spectrum Spotlight 300 spectrometer (Perkin Elmer, USA). Physical properties of DPNR rubber were determined in accordance with SMR Bulletin No. 7-1992 for dirt content, volatile matter content, ash content, initial Wallace plasticity $\left(P_{0}\right)$, and plasticity retention index (PRI) and Mooney viscosity.

\section{Results and Discussion}

3.1. Effects of EDTA-4Na Concentration. In order to determine the optimal dosage of EDTA-4Na on deproteinization, the nonammonia and ammonia latices were incubated with EDTA-4Na at various concentrations $(0.05,0.10$, and $0.20 \mathrm{wt} \%$ ) in the presence of $1 \mathrm{wt} \%$ SDS at room temperature for $1 \mathrm{~h}$. Separation and washing of the cream fraction in the presence of $1 \mathrm{wt} \%$ SDS were later carried out. The final cream 
TABLE 1: Nitrogen content of FNR and deproteinized FNR (DPNR) by using EDTA-4Na at various concentrations.

\begin{tabular}{|c|c|c|c|c|}
\hline Samples & Preservative & $\mathrm{pH}$ & EDTA-4Na (wt\%) & Nitrogen content (wt\%) \\
\hline FNR & - & 6.5 & - & 0.638 \\
\hline FR-NH 3 & Ammonia & 10 & - & 0.587 \\
\hline FR-SH & $\mathrm{SH}$ & 10 & - & 0.551 \\
\hline FR-NH 3 & Ammonia & 10 & 0.05 & 0.043 \\
\hline FR-NH 3 & Ammonia & 10 & 0.10 & 0.009 \\
\hline FR-NH 3 & Ammonia & 10 & 0.20 & 0.008 \\
\hline FR-SH & $\mathrm{SH}$ & 10 & 0.05 & 0.012 \\
\hline FR-SH & $\mathrm{SH}$ & 10 & 0.10 & 0.005 \\
\hline FR-SH & $\mathrm{SH}$ & 10 & 0.20 & 0.005 \\
\hline
\end{tabular}

TABLE 2: Magnesium ion content of FNRL and FNRL deproteinized by using EDTA-4Na.

\begin{tabular}{|c|c|c|c|}
\hline Samples & Preservatives & EDTA-4Na (wt\%) & $\mathrm{Mg}^{2+}$ content $(\mathrm{ppm})$ \\
\hline FNRL & - & - & 657 \\
\hline FR-NH ${ }_{3}$ & Ammonia & - & 294 \\
\hline FR-SH & $\mathrm{SH}$ & - & 635 \\
\hline FR-NH ${ }_{3}$ DPNR & Ammonia & 0.05 & 152 \\
\hline FR-NH ${ }_{3}$ DPNR & Ammonia & 0.10 & 123 \\
\hline FR-NH ${ }_{3}$ DPNR & Ammonia & 0.20 & 89 \\
\hline FR-SH DPNR & $\mathrm{SH}$ & 0.05 & 417 \\
\hline FR-SH DPNR & $\mathrm{SH}$ & 0.10 & 341 \\
\hline FR-SH DPNR & $\mathrm{SH}$ & 0.20 & 289 \\
\hline
\end{tabular}

fraction was redispersed in distilled water to make DPNR latex with $30 \%$ dry rubber content (DRC).

The total nitrogen contents of the fresh natural rubber (FNR) and deproteinized natural rubber (DPNR) is shown in Table 1 . The nitrogen content of the air-dried FNR film was $0.638 \%$. Increasing dosage of EDTA-4Na led to a decreasing trend of nitrogen content in the deproteinized NR preserved by both methods. Treatment of FR- $\mathrm{NH}_{3}$ with $0.20 \mathrm{wt} \%$ EDTA-4Na led to a remarkable decrease of the nitrogen content from $0.587 \mathrm{wt} \%$ to $0.008 \mathrm{wt} \%$. Moreover, the total nitrogen content of FR-SH DPNR was found to be the lowest when $0.10 \mathrm{wt} \%$ EDTA- $4 \mathrm{Na}$ was used which resulted in the final nitrogen content of $0.005 \mathrm{wt} \%$ compared with $0.551 \mathrm{wt} \%$ of the untreated sample, FR-SH.

According to the results in Table 2, the $\mathrm{Mg}^{2+}$ content of FNRL was decreased from 657 to $294 \mathrm{ppm}$ after the fresh latex was preserved with $\mathrm{NH}_{4} \mathrm{OH}$. This was due to the complex formation of magnesium ammonium phosphate $\left(\mathrm{MgNH}_{4} \mathrm{PO}_{4}\right)$ when magnesium and phosphate ions of the fresh latex reacted with ammonia ion. The $\mathrm{Mg}^{2+}$ content of FR-NH $\mathrm{NH}_{3}$ DNPR samples tended to reduce with increasing EDTA-4Na dosage, resulting in the lowest $\mathrm{Mg}^{2+}$ content (89 ppm) at $0.20 \mathrm{wt} \%$ EDTA-4Na. The $\mathrm{Mg}^{2+}$ content of FR$\mathrm{SH}$ sample was slightly reduced compared to that of the starting material (FNRL). Again, the $\mathrm{Mg}^{2+}$ content of the nonammonia latex tended to decrease with increasing EDTA$4 \mathrm{Na}$ content; that is, the lowest $\mathrm{Mg}^{2+}$ content (289 ppm) was found in the latex treated with $0.20 \mathrm{wt} \%$ EDTA-4Na. The results demonstrated that the magnesium ions present in the fresh NR latex could be scrapped by EDTA-4Na chelating agent under the same conditions used for deproteinization.

Effect of different EDTA salt complexes on deproteinization of nonammonia and ammonia NR latices was studied. As shown in Table 3, the highest deproteinization efficiency was observed with EDTA-4Na and tended to be lower with decreasing $\mathrm{Na}$ number in the complex. The lowest nitrogen contents of $0.008 \mathrm{wt} \%$ and $0.005 \mathrm{wt} \%$ were obtained for FR$\mathrm{NH}_{3}$ DPNR and FR-SH-DPNR treated with $0.10 \mathrm{wt} \%$ EDTA$4 \mathrm{Na}$, respectively. EDTA-1Na, EDTA-2Na, and EDTA-3Na could also remove proteins by denaturation. The highest efficiency of EDTA-4Na on deproteinization could be due to its higher solubility in water compared to the other EDTA complexes. Removal of proteins in NR by EDTA suggested that most proteins present in fresh NR are attached to the rubber via weak attractive forces, which can be disturbed by chelation. Huang and coworkers reported that the coordination of metal ion with protein was destroyed by scrapping of metal by EDTA resulting in the denaturation of NR proteins [13].

Removal of divalent metal ions can result in denaturation of the proteins associated with the latex particles due to disturbance of the protein's structure [14]. The highest efficiency of EDTA-4Na on deproteinization of NR followed by EDTA-3Na, EDTA-2Na, and EDTA-1Na, respectively, can be explained by the chemical characteristics of the different EDTA complexes. EDTA in different forms have different capability on chelating divalent metal ions. According to 
TABLE 3: Nitrogen content of FNR and deproteinized FNR prepared using various EDTA complexes at $0.10 \mathrm{wt} \%$.

\begin{tabular}{lcccc}
\hline Samples & Preservatives & $\mathrm{pH}$ & 0.1 wt\% EDTA complexes & Nitrogen content (wt\%) \\
\hline FNR & - & 6.5 & - & 0.638 \\
FR-NH & & - & 0.587 \\
FR-SH & Ammonia & 10 & - & 0.551 \\
$\mathrm{FR}_{3} \mathrm{NH}_{3}$ & $\mathrm{SH}$ & 10 & EDTA-1Na & 0.029 \\
$\mathrm{FR}_{\mathrm{NH}}$ & Ammonia & 10 & EDTA-2Na & 0.022 \\
$\mathrm{FR}_{3} \mathrm{NH}_{3}$ & Ammonia & 10 & EDTA-3Na & 0.013 \\
FR-NH & Ammonia & 10 & EDTA-4Na & 0.008 \\
FR-SH & Ammonia & 10 & EDTA-1Na & 0.022 \\
FR-SH & SH & 10 & EDTA-2Na & 0.012 \\
FR-SH & SH & 10 & EDTA-3Na & 0.009 \\
FR-SH & SH & 10 & EDTA-4Na & 0.005 \\
\hline
\end{tabular}<smiles></smiles>

EDTA-1Na<smiles>CCCCNN(CCCC)C(=O)[OH+]</smiles>

EDTA-2Na<smiles>[NH3+]OC(=O)CN(CCN(CC(=O)O)CC(=O)O[Na])CC(=O)[OH2+]</smiles>

EDTA-3Na<smiles>[NH3+]OC(=O)CN(CCN(CC(=O)[O-])CC(=O)[O-])CC(=O)[OH2+]</smiles>

EDTA-4Na

FIGURE 2: Chemical structures of EDTA.

their chemical structures (see Figures 2 and 3), EDTA-4Na can chelate two divalent metal ions on stoichiometry basis. Lower chelating efficiency is expected for EDTA-3Na, EDTA$2 \mathrm{Na}$, and EDTA-1Na, respectively. Solubility of the EDTA complexes in water also follows this order where EDTA-4Na showed the highest solubility. In addition, solubilization of EDTA-4Na led to $\mathrm{pH}$ between 10 and 11, which was very close to the $\mathrm{pH}$ of the NR samples while solubilization of EDTA$3 \mathrm{Na}$, EDTA-2Na, and EDTA-1Na resulted in solution with less alkaline $\mathrm{pH}$, respectively. Altogether, this resulted in the highest deproteinization efficiency of EDTA-4Na as observed in this study.

3.2. Determination of Proteins Pattern of DPNR-EDTA. Protein patterns in the cream fractions of NR samples deproteinized by different forms of EDTA were determined using SDS-PAGE.

Figures 4 and 5 show the protein patterns in the FNRL and deproteinized ammonia and nonammonia NR samples separated according to their molecular weight. Overall treatment with EDTA under the experimental conditions led to decomposition of proteins to fragments with lower molecular weights. The protein patterns of the controls (FR-SH and FR$\mathrm{NH}_{3} \mathrm{FNRL}$ ) are shown in lane 1. The major bands at 14.4 and $25 \mathrm{kDa}$ are known to be derived from proteins covering the surface of the rubber latex particle [15]. Slight degradation of proteins was observed in FNRL treated with EDTA (in lane 3). Distinct decomposition of proteins was found in DPNR with EDTA-4Na, EDTA-3Na, EDTA-2Na, and EDTA-1Na which resulted in protein bands with lower molecular weight and smear. No significant difference was observed between samples treated with different forms of EDTA complexes.

3.3. FT-IR Spectra of DPNR-EDTA-4Na. The residual proteins of ammonia and nonammonia fresh latices treated with $0.10 \mathrm{wt} \%$ EDTA-4Na were analyzed by FT-IR (Figure 6). For fresh NR latex, the clear peak at $3280 \mathrm{~cm}^{-1}$ assigned to $\mathrm{NH}$ stretching was found indicating the existence of proteins or 


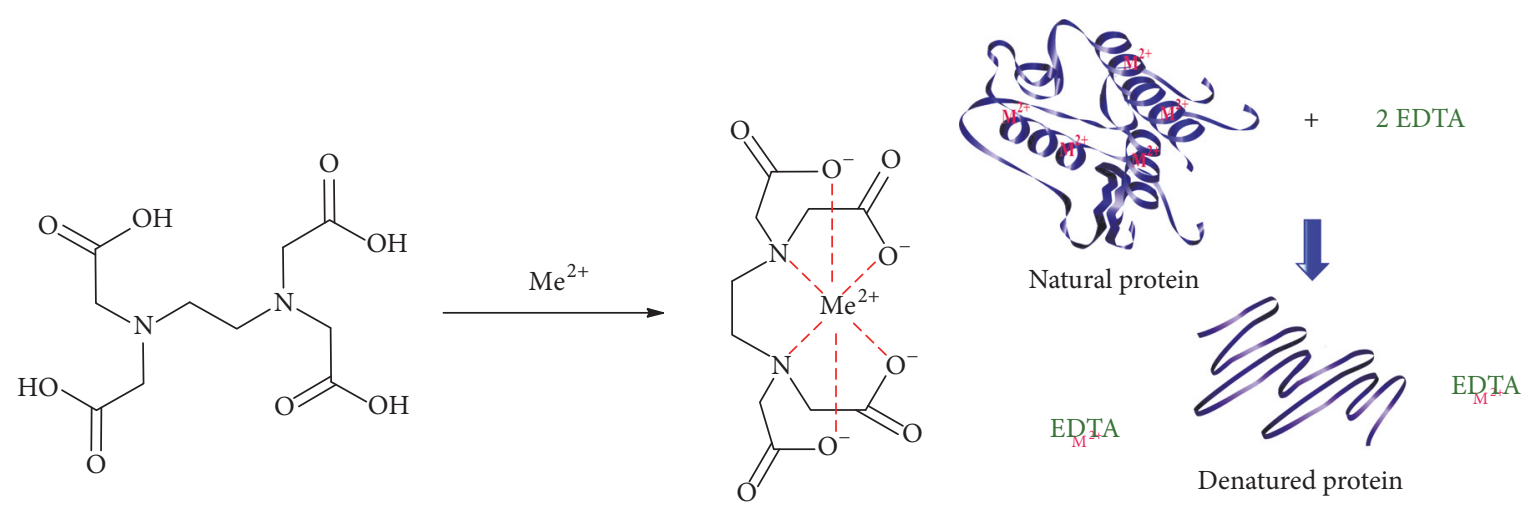

(a)

(b)

FIGURE 3: Mechanism of chelation reaction with metal ions and metal ions on protein: (a) mechanism of chelation reaction; (b) metal ions in the protein layer was scraped by EDTA.

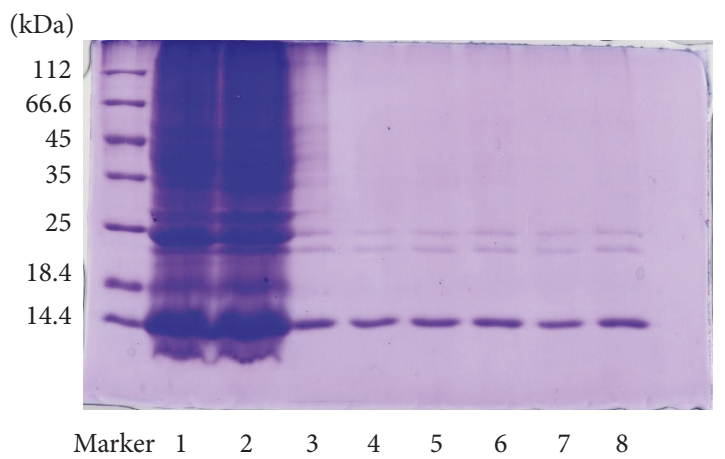

FIGURE 4: SDS-PAGE of redispersed cream fraction from deproteinized nonammonia FNRL with EDTA complexes. FN-SH samples were incubated with $0.1 \mathrm{wt} \%$ EDTA in different forms in the presence of $1 \mathrm{wt} \% \mathrm{SDS}$ for $1 \mathrm{~h}$. Lane 1: FR-SH, lane 2: mixture of FR$\mathrm{SH}$ and EDTA-4Na without centrifugation, lane 3: washed FR-SH with SDS followed by centrifugation, lane 4: FR-SHDPNR-EDTA, lane 5: FR-SHDPNR-EDTA-1Na, lane 6: FR-SHDPNR-EDTA-2Na, lane 7: FR-SHDPNR-EDTA-3Na, and lane 8: FR-SHDPNR-EDTA$4 \mathrm{Na}$.

peptides. After deproteinization with $0.10 \mathrm{wt} \%$ EDTA-4Na,

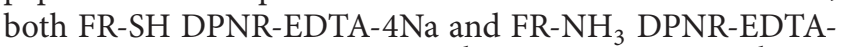
$4 \mathrm{Na}$ show their peak at $3320 \mathrm{~cm}^{-1}$ instead of $3280 \mathrm{~cm}^{-1}$. The newly appeared band around $3320 \mathrm{~cm}^{-1}$ in the purified NR was assigned to the $\mathrm{NH}$ stretching of oligopeptides such as dipeptide $[5,16,17]$. The absence of $\mathrm{NH}$ stretching band in FR-SH DPNR-EDTA-4Na and FR-NH $\mathrm{NH}_{3}$ DPNR-EDTA$4 \mathrm{Na}$ indicated that the amount of residual proteins in these samples was less than the detection limit of FT-IR analysis.

3.4. Physical Properties of DPNR. Physical properties of the DPNR prepared using the two different preservative systems with $0.10 \mathrm{wt} \%$ EDTA-4Na are compared with relevant international specifications according to the Standard Thai Rubber STR5L in Table 4.

The dirt content, volatile matter content, ash content, nitrogen content, and Mooney viscosity of both deproteinized NR samples were conformed to the specifications.

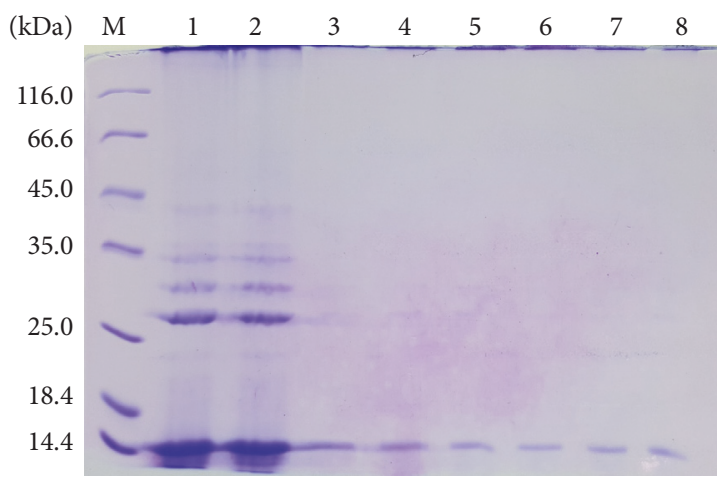

FIGURE 5: SDS-PAGE of redispersed cream fraction from deproteinized ammonia FNRL with EDTA complexes. $\mathrm{FN}-\mathrm{NH}_{3}$ was incubated with $0.10 \mathrm{wt} \%$ of EDTA in different forms for 1 hour at room temperature in the presence of $1 \mathrm{wt} \%$ SDS. Lane 1: FR- $\mathrm{NH}_{3}$, lane 2: mixture of FR- $\mathrm{NH}_{3}$ and EDTA- $4 \mathrm{Na}$ without centrifugation, lane 3: washed FR- $\mathrm{NH}_{3}$ with SDS followed by centrifugation, lane 4: FR- $\mathrm{NH}_{3}$ DPNR-EDTA, lane 5: FR-NH ${ }_{3}$ DPNR-EDTA-1Na, lane 6: FR-NH ${ }_{3}$ DPNR-EDTA-2Na, lane 7: FR-NH ${ }_{3}$ DPNR-EDTA-3Na, and lane 8: FR- $\mathrm{NH}_{3}$ DPNR-EDTA-4Na.

Exception was found for the PRI; that is, the PRI values for FR-SH DPNR-EDTA-4Na and FR-NH ${ }_{3}$ DPNR-EDTA-4Na were 40.5 and 37.6, respectively. The results imply that the two DPNR samples possessed relatively low thermal oxidative aging resistance. This could be explained by the low protein content in the samples because it has been reported that natural proteins or amino acids in NR could act as natural antioxidant [18]. The presence of remnant oligopeptides or small protein fragments in DPNR and the nearly complete removal of proteins by surfactant washing could be assessed indirectly by measuring the resistance to thermal oxidative aging represented in terms of plasticity retention index (PRI).

\section{Conclusions}

The deproteinized natural rubber (PDNR) was successfully prepared in the latex stage for both preservative systems by 


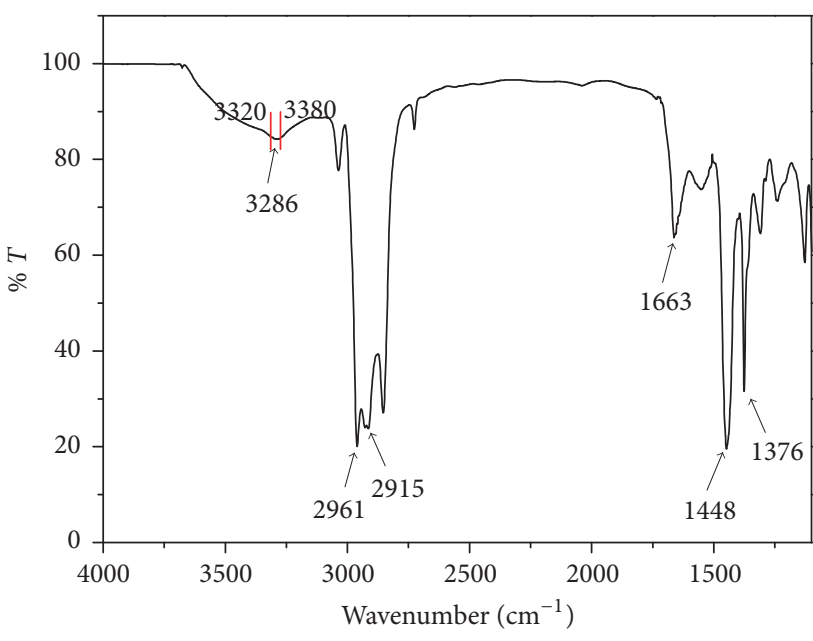

(a)

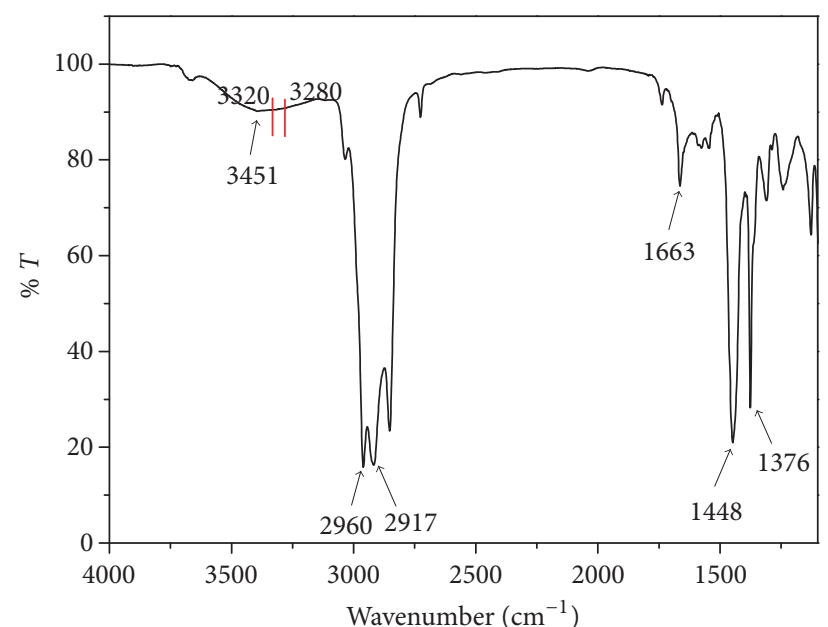

(b)

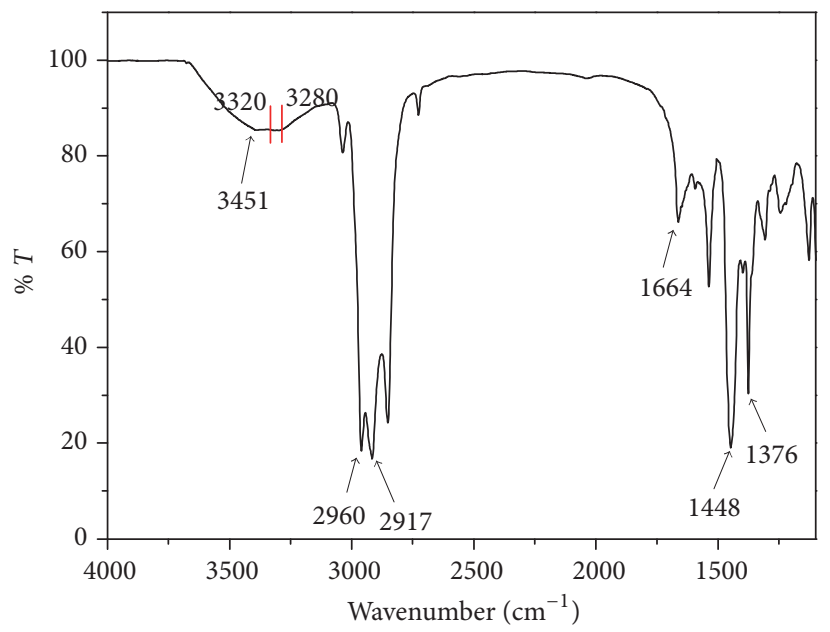

(c)

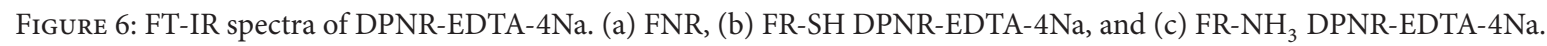

TABLE 4: Physical properties of DPNR.

\begin{tabular}{|c|c|c|c|}
\hline \multirow{2}{*}{ Properties } & \multicolumn{3}{|c|}{ Samples } \\
\hline & Standard of STR 5L & FR-SH DPNR-EDTA-4Na & FR-NH ${ }_{3}$ DPNR-EDTA-4Na \\
\hline Dirt content (wt\%) & $0.04 \max$ & 0.004 & 0.003 \\
\hline Volatile matter content (wt\%) & $0.8 \max$ & 0.03 & 0.03 \\
\hline Ash content (wt\%) & $0.4 \max$ & 0.11 & 0.13 \\
\hline Nitrogen content (wt\%) & $0.6 \max$ & 0.005 & 0.008 \\
\hline Initial Wallace plasticity $\left(P_{0}\right)$ & $35 \mathrm{~min}$ & 55.5 & 50.0 \\
\hline Plasticity retention index (PRI) & $60 \mathrm{~min}$ & 40.5 & 37.6 \\
\hline Mooney viscosity, $\mathrm{ML}(1+4) 100^{\circ} \mathrm{C}$ & - & 67.0 & 66.3 \\
\hline Color (Lovibond) & $6.0 \max$ & 1.0 & 1.5 \\
\hline
\end{tabular}

using EDTA-4Na in the presence of surfactant. The optimum concentration of EDTA-4Na was $0.1 \mathrm{wt} \%$ while EDTA-1Na, EDTA-2Na, and EDTA-3Na could also remove protein but with lower efficiency. The magnesium ion content of the FNRL was reduced with increasing EDTA-4Na concentration. The nonammonia preservative has no strong smell, is free of nitrosamine, and is nontoxic to cell with adjustable $\mathrm{pH}$
(8-11). These properties are considered useful for application in producing healthcare products.

\section{Conflicts of Interest}

The authors declare that there are no conflicts of interest regarding the publication of this paper. 


\section{References}

[1] Y. Tanaka, "Structural characterization of natural polyisoprenes: solve the mystery of natural rubber based on structural study," Rubber Chemistry and Technology, vol. 74, no. 3, pp. 355-375, 2001.

[2] P. W. Allen and G. F. Bloomfield, Chemistry and Physics of Rubber Like Substances, L. Bateman, Ed., vol. 51, Maclaren and Sons, London, UK, 1963.

[3] J. W. Yunginger, R. T. Jones, A. F. Fransway, J. M. Kelso, M. A. Warner, and L. W. Hunt, "Extractable latex allergens and proteins in disposable medical gloves and other rubber products," The Journal of Allergy and Clinical Immunology, vol. 93, no. 5, pp. 836-842, 1994.

[4] P. A. J. Yapa and W. S. E. Fernando, "Enhancement of deproteinization of Hevea rubber by maturation of papain treated Hevea latex," Vidyodaya Journal of Science, vol. 7, pp. 93-100, 1997.

[5] A. H. Eng, Y. Tanaka, and S. N. Gan, "Short communication FTIR-studies on amino group in purified Havea rubber," Journal of Natural Rubber Research, vol. 7, p. 152, 1992.

[6] J. Yunyongwattanakorn, Y. Tanaka, J. Sakdapipanich, and V. Wongsasutthikul, "Highly-purified natural rubber by saponification of latex: Analysis of residual proteins in saponified natural rubber," Rubber Chemistry and Technology, vol. 81, no. 1, pp. 121-137, 2008.

[7] N. Ichikawa, A. H. Eng, and Y. Tanaka, 1993, Proc. Inter. Rubber Technol. Conf., Kuala Lumpur, Malaysia, 101.

[8] S. Nakade, G. Kuga, M. Hayashi, and Y. Tanaka, "Highly purified natural rubber IV. Preparation and characteristics of gloves and condoms," Journal of Natural Rubber Research, vol. 12, no. 1, pp. 33-42, 1997.

[9] P. K. Viswanath, J. K. Kevin, R. Abe, K. B. Naveen, and N. F. Jordan, "Characterization of latex antigen and demonstration of latex-specific antibodies by enzyme-linked immunosorbent assay in patients with latex hypersensitivity," Allergy and Asthma Proceedings, vol. 13, no. 6, pp. 329-334, 1992.

[10] S. loykulnant, C. Kongkaew, and O. Chaikumpollert, A method for preservation of natural rubber latex using methylol compounds, National Science and Technology Development Agency, 2010, Malaysia patent MY142541 (A).

[11] U. K. Laemmli, "Cleavage of structural proteins during the assembly of the head of bacteriophage T4," Nature, vol. 227, no. 5259, pp. 680-685, 1970.

[12] 1973, Rubber Res Inst Malaysia SMR Bull, 17.

[13] Z. Huang, H. Zhang, W. Yao, Y. Liu, J. Zhou, and L. Tang, "Raman spectroscopy study of zinc finger ZNF191(243-368)," Chinese Science Bulletin, vol. 48, no. 16, pp. 1722-1727, 2003.

[14] M. M. Rippel, C. A. P. Leite, L.-T. Lee, and F. Galembeck, "Formation of calcium crystallites in dry natural rubber particles," Journal of Colloid and Interface Science, vol. 288, no. 2, pp. 449456, 2005.

[15] G. M. Bristow, “The huggin's $k^{\prime}$ parameter for polyisoprenes," Journal of Polymer Science, vol. 62, no. 174, 168 pages, 1962.

[16] A. H. Eng, S. Kawahara, and Y. J. Tanaka, "Structural characteristic of natural rubber-roles of ester groups," Journal of Applied Polymer Science. Applied polymer symposium, vol. 53, no. 5, 1994.

[17] Y. Tanaka, S. Tangpakdee, and J. Kautsch, GummiKunstst, 1997, $69,6$.

[18] R. F. A. Altman, "Natural antioxidants in hevea latex," Rubber Chemistry and Technology, vol. 21, no. 3, pp. 752-764, 1948. 

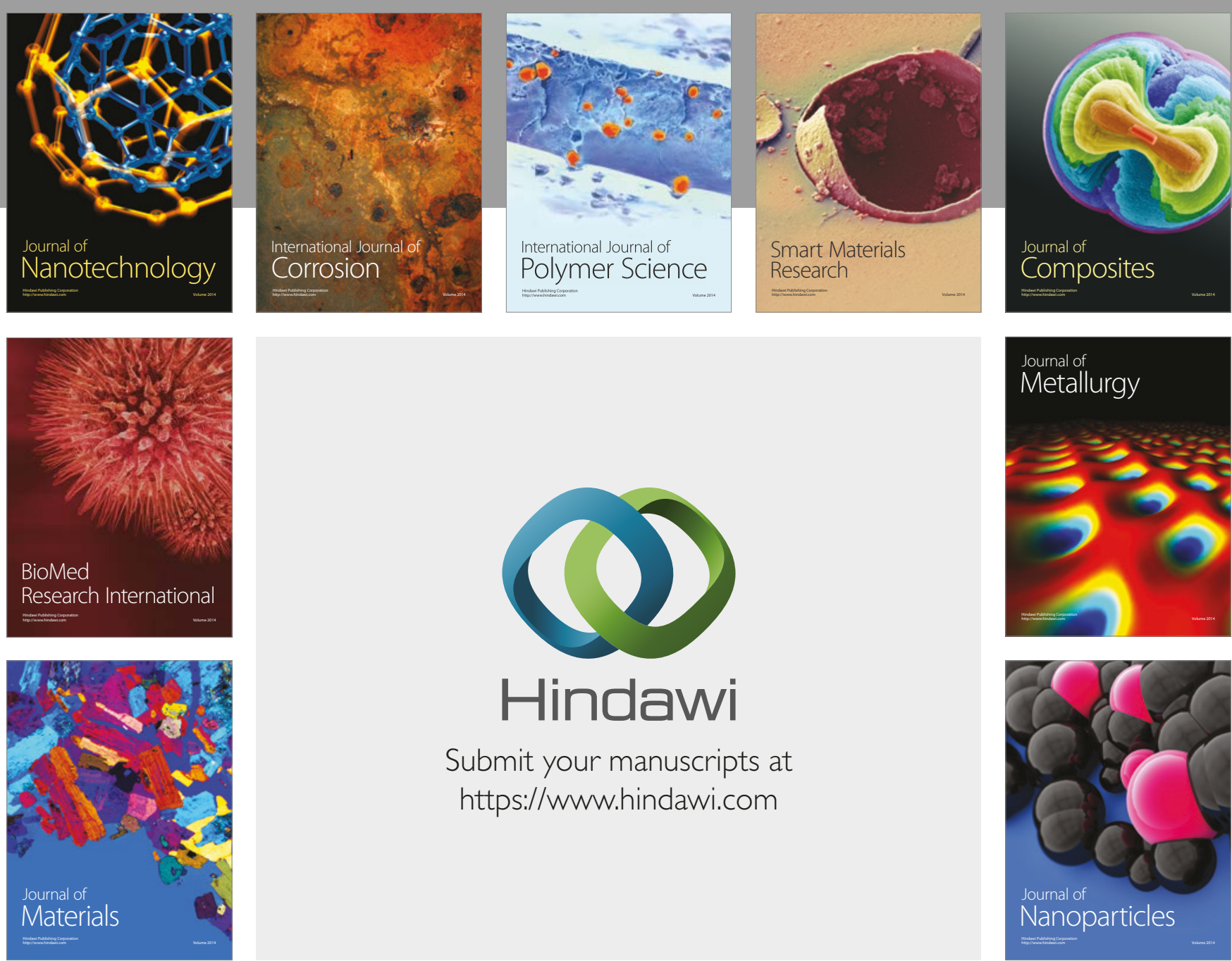

\section{Hindawi}

Submit your manuscripts at

https://www.hindawi.com
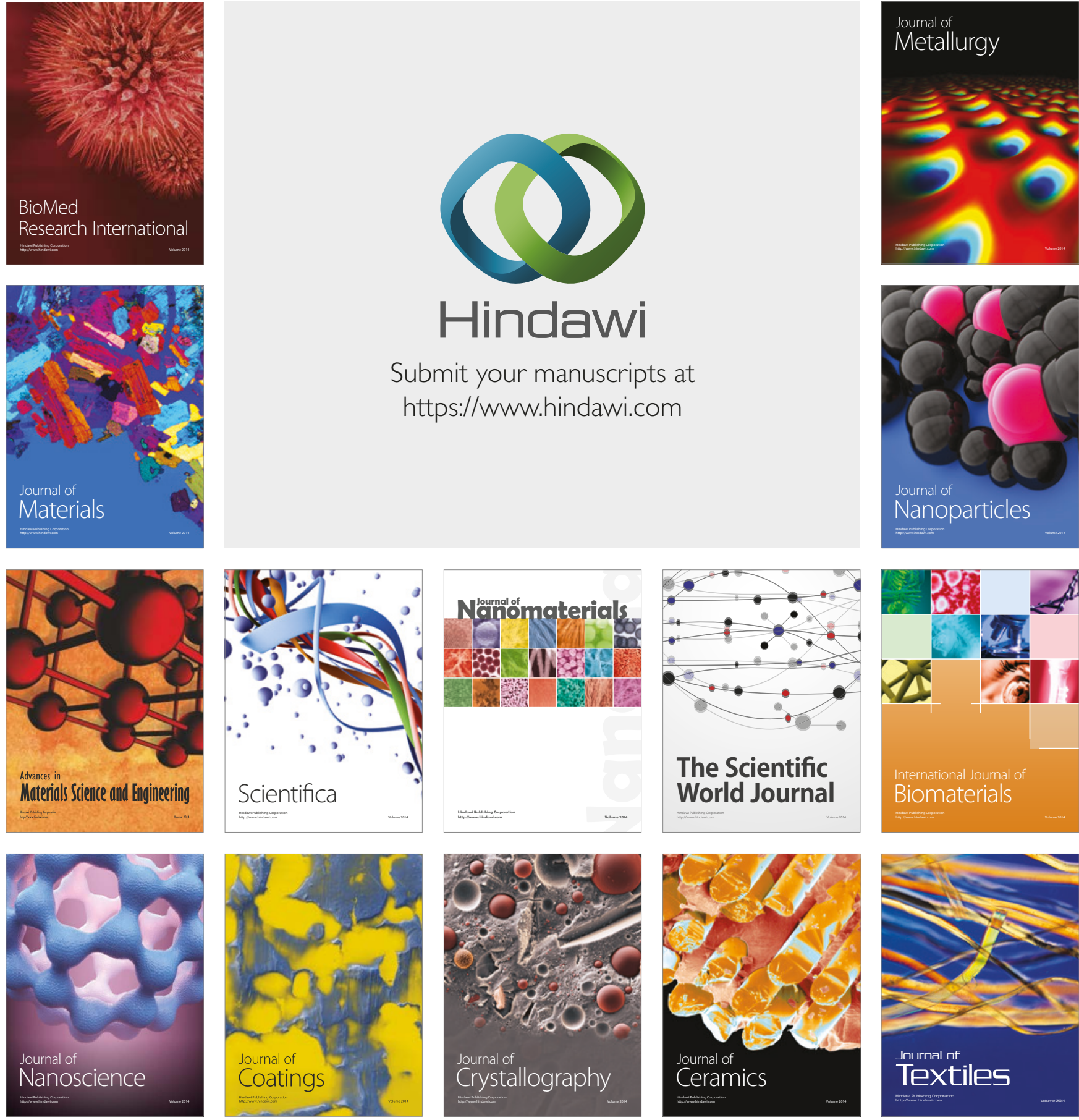

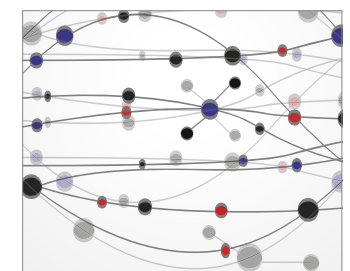

The Scientific World Journal
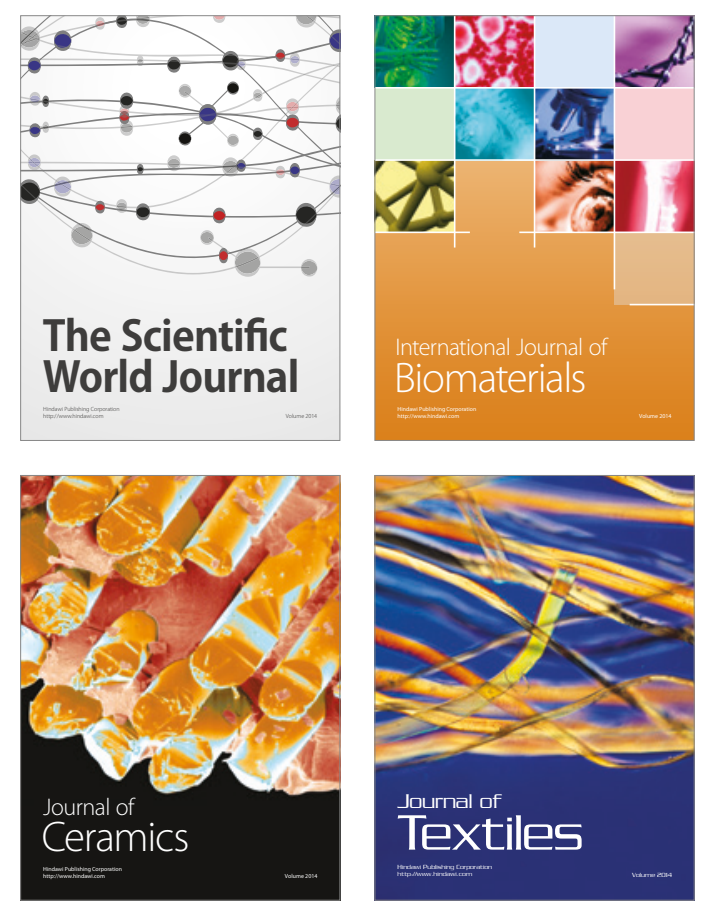